\title{
Water scarcity in the Arabian Peninsula and socio-economic implications
}

\author{
George O. Odhiambo ${ }^{1}$
}

Received: 10 June 2015/Accepted: 8 June 2016/Published online: 21 June 2016

(c) The Author(s) 2016. This article is published with open access at Springerlink.com

\begin{abstract}
The Arabian Gulf, one of the driest parts of the world, is already passing the water scarcity line as defined by the World Health Organization (WHO). The scarcity of renewable water resources and the growing discrepancy between demand and supply of water is a major challenge. Water scarcity is further worsened by rapidly growing demands due to rapid population growth, unsustainable consumption, climate change and weak management institutions and regulations. Water scarcity erodes the socio-economic sustainability of the communities that depend on the depleting storage. In this paper, an analysis of the water security situation within the Arabian Gulf region and the consequent socio-economic implications is presented.
\end{abstract}

Keywords Arabian Peninsula - Water scarcity · Climate change - Groundwater - Socio-economic development . Population growth

\section{Introduction}

Water is one of the most vital natural resource and crucial for survival of all living organisms; essential for agriculture, domestic use (including drinking, cooking, and hygiene), industrial input, tourism and culture, and sustaining the earth's ecosystems. The environment, economy, and development of any country are significantly influenced by the regional and seasonal variation in the available quantity and

George O. Odhiambo

godhiambo@uaeu.ac.ae

1 Department of Geography and Urban Planning, FHSS, UAE University, P. O. Box 15551, Al Ain, United Arab Emirates quality of surface and groundwater (UN Water 2012). In recent times, it has become clearer that human prosperity and prospects for survival vary with the amount and distribution of fresh, unpolluted water (Gleick 2012).

This research reviews the water scarcity and availability in the Arabian Gulf/Peninsula (Fig. 1) and assesses the socio-economic consequences of the rapid population growth, heavily subsidised water tariff in the region, and climate change on water scarcity.

A key characteristic of the world's freshwater resource is its uneven spatial and temporal distribution and variability which is dictated largely by climate: with conditions ranging from arid deserts, with almost no rainfall, to the most humid regions, which can receive hundreds millimetres of rainfall a year. The availability of water resources, in total and on a per-capita basis, therefore varies considerably between and within countries and regions. In arid regions, freshwater resources may at times be limited to the extent that demand for water can be met only by going beyond sustainable use. Indeed climatic conditions determine which regions receive abundant precipitation and which areas are dry/arid, thereby influencing water resource availability. In countries within the tropical and temperate regions, due to enough precipitation, abundant volume of water is available for each person annually. On the other hand, there is an acute shortage of water resources in drier regions within the arid and semi-arid climatic zones. In the latter group of countries, average water availability is extremely scarce.

Water security is "the availability of, and access to water sufficient in quantity and quality to meet the health, livelihoods, ecosystem and production needs of populations, coupled with an acceptable level of water-related risk". Water security can be considered from four different dimensions (FAO 2003): 
Fig. 1 Map of the Arabian Peninsula

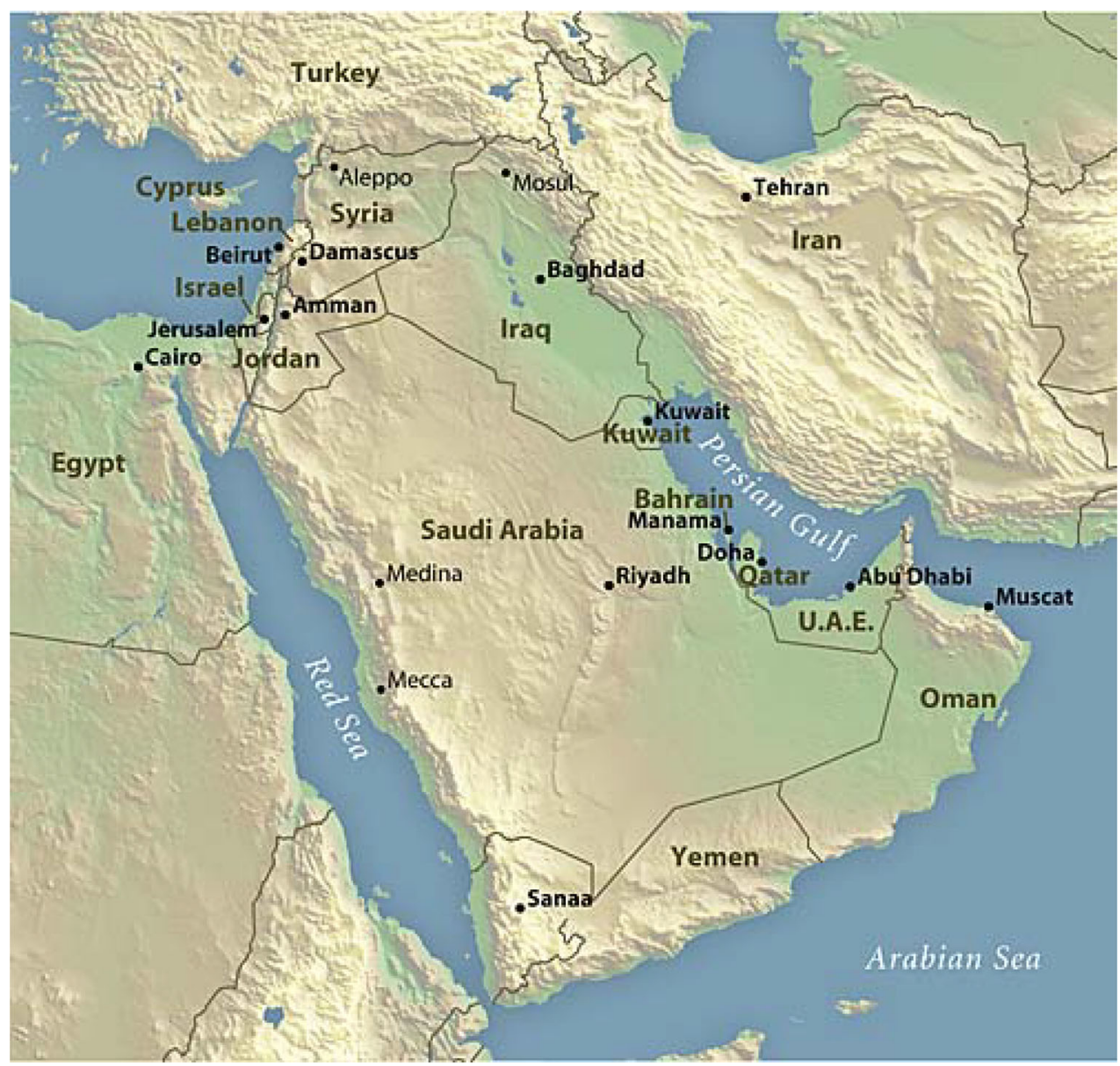

- Little or no water scarcity. Abundant water resources relative to use, with less than $25 \%$ of water from rivers withdrawn for human purposes.

- Physical water scarcity is the situation where there is not enough water to meet all demands, including that needed for ecosystems to function effectively. Arid regions frequently suffer from physical water scarcity.

- Economic water scarcity occurs when human, institutional, and financial capital limit access to water, even though water in nature is available locally to meet human demands.

- A nation is considered "water stressed" if its total renewable freshwater resources are between 1000 and $1700 \mathrm{~m}^{3}$ per person annually.

\section{Water scarcity in the Arabian Peninsula}

In Arabian Peninsula, ready availability of fresh water has always been a major concern. The region is one of those with the lowest absolute and per inhabitant water resources (Osman-Elasha 2010). Throughout history, the scarcity of water in the region has affected the lives and livelihood of inhabitants. A remarkable variety of adjustments to watersupply fluctuations and deficits have been made by indigenous people over the years. More recently, however, socio-economic development, high population growth, as well as expanded urbanisation and agricultural activity have placed substantial strains on the water resources in the region.

All the countries in the region are situated in arid and extremely arid zones: a large portion of which is mostly desert with the exception of narrow coastal areas and mountain ranges. These areas are characterised by large variability in rainfall, limited renewable groundwater resources, problems with groundwater salinity, and the absence of fresh surface water bodies such as rivers and lakes. Precipitation in the region is very low and variable (see Table 1), and the region's water resources are particularly sensitive to drought. The average annual rainfall ranges from 70 to $130 \mathrm{~mm}$ (see Table 1) except in the coastal zone along the Red Sea in south-western Saudi Arabia and along the Gulf of Oman on the eastern shore, where orographic rainfall occasionally reaches more than $500 \mathrm{~mm}$. The total annual evaporation rate ranges from $2500 \mathrm{~mm}$ in the coastal areas to more than $4500 \mathrm{~mm}$ 
Table 1 Availability of water resources in the Arabian Peninsula Data Source: FAO and AQUASTAT 2012, World Bank (2011). Renewable internal freshwater resources per capita (cubic meters) Accessed from: http://data.worldbank.org/indicator/ER.H2O.INTR.PC on 16th September, 2014

\begin{tabular}{lllllll}
\hline Country & $\begin{array}{l}\text { Area } \\
\left(\mathrm{Km}^{2}\right)\end{array}$ & $\begin{array}{l}\text { Mean annual } \\
\text { precipitation }(\mathrm{mm})\end{array}$ & $\begin{array}{l}\text { Groundwater } \\
\text { recharge }\left(\mathrm{M} \mathrm{m}^{3}\right)\end{array}$ & $\begin{array}{l}\text { Non-renewable } \\
\text { reserve }\left(\mathrm{M} \mathrm{m}^{3}\right)\end{array}$ & $\begin{array}{l}\text { Annual renewable water } \\
\text { resources }\left(\mathrm{Km}^{3} / \text { year }\right)\end{array}$ & $\begin{array}{l}\text { Total renewable water resources } \\
\text { per capita }\left(\mathrm{m}^{3} / \text { year/per. }\right)\end{array}$ \\
\hline Bahrain & 652 & $30-140$ & 110 & Negligible & 11.6 & 7.65 \\
Kuwait & 17,818 & $30-140$ & 160 & n/a & 58.3 & 6.154 \\
Oman & 212,460 & $80-400$ & 900 & 102,000 & 0.6 & 462.84 \\
Qatar & 11,610 & $20-150$ & 50 & Negligible & 29 & 29.30 \\
Saudi & $2,149,690$ & $30-550$ & 3850 & 428,400 & 33.7 & 86.45 \\
$\quad$ Arabia & & & & n/a & 64.5 & 16 \\
UAE & 83,600 & $80-160$ & 190 & &
\end{tabular}

inland. The amount of renewable aquifer volume is very limited and shallow alluvial aquifers provide some renewable groundwater only in those limited coastal strips (FAO and AQUASTAT 2012). Large deep aquifers are present in the region, which contain non-renewable supplies of fossil water, but have a finite life and quality limitations. Only Saudi Arabia possesses substantial amounts of non-renewable groundwater in deep aquifers amounting to 430 billion cubic metres (BCM) (Al-Alawi and Abdulrazzak 1994). However, even these are rapidly depleting (Table 1).

While the Arabian Gulf region covers approximately $4.7 \%$ of the world's total land area and contains $4.25 \%$ of its population, the region's water resources are only about $1.1 \%$ of the world's total renewable water resources (FAO 2007). Renewable water availability is less than $100 \mathrm{~m}^{3}$ per person-year in places like Kuwait, Bahrain and Qatar. For the region as a whole, renewable shallow groundwater circulation associated with alluvial deposits in wadi channels and extensive alluvial fans are important sources of potable water, stock watering and localised irrigation. The resources of these localised aquifer systems are dependent on indirect recharge from intermittent flows in watercourses. Other sources of renewable groundwater are also obtained from where outcrops of permeable limestone and sandstones accept direct recharge from rainfall (World Bank 2005). The groundwater in these shallow aquifers is the only renewable water sources for the Arabian Peninsula region (FAO 2008). The shallow aquifers in the eastern part of the peninsula, particularly in the United Arab Emirates and Oman, are generally thicker and wider than in the west, while alluvial thickness in the inland basins is greater than in those of the coastal basins. Alluvial aquifer thicknesses generally range from 20-200 m (FAO and AQUASTAT 2012), with the exception of the coastal areas of Oman where thicknesses may reach $400 \mathrm{~m}$. The width of these alluvial aquifers may range from a few $100 \mathrm{~m}$ to several kilometres, but decreases in a southerly direction for basins on both the western and eastern coasts. The coastal alluvial aquifers are subject to salt water intrusion, especially on the Gulf, as a result of extensive groundwater withdrawals. Shallow aquifer water quality is generally good, with total dissolved solids being low. Combined reserves of the alluvial aquifers are estimated at $131 \mathrm{BCM}$ (Al-Alawi and Abdulrazzak 1994), with the largest reserves for the numerous basins in Saudi Arabia, estimated at 84 BCM (FAO, 2007). Groundwater from the shallow alluvials is sometimes used for domestic and irrigation purposes. However, poor groundwater quality in the downstream areas may limit its use for meeting domestic needs.

\section{Groundwater}

The other main source of water for the countries of the Arabian Peninsula is the non-renewable fossil groundwater stored in the sedimentary deep aquifers. The sandstone and limestone geological formations of the Arabian Shelf store significant amounts of groundwater that are thousands of years old (Edgell 1987). The sedimentary aquifers have been classified as either primary or secondary, based on their areal extent, groundwater volume, water quality, and development potential (UNESCO 2009). These aquifers cover two-thirds of Saudi Arabia and some of them extend into Kuwait, Bahrain, Qatar, the United Arab Emirates, Oman, and Yemen, as well as into Jordan, Syria, and Iraq. Vast amounts of groundwater stored in the primary deep aquifers serve as a dependable source of water for the central and northern regions of Saudi Arabia, and, to a lesser extent, the other countries of the peninsula. Deep groundwater reserves for the aquifers in the peninsula are estimated at $2175 \mathrm{BCM}$, with the major portion (1919 BCM) located in Saudi Arabia. Recharge for all the deep aquifers is estimated at a very limited 2.7 BCM per year (UN Water 2012). This reserve represents groundwater exploitable by lowering the water level to $300 \mathrm{~m}$ below the ground surface, the maximum depth currently possible with 
modern pumping technology. Although water in the deep aquifers is in large quantity, the quality varies greatly and is suitable for domestic consumption in only a few areas. Total dissolved solids range from 400 to $20,000 \mathrm{ppm}$. Good-quality water is stored in only a few aquifers: the Saq, Tabuk, and Wajid in Saudi Arabia, and the Dammam in Bahrain and Kuwait. Brackish water from the Minjur, Wasia, Biyadh, and Um er-Radhuma aquifers usually requires treatment in most of the countries for hardness and high temperature. Water from these deep aquifers tends to be saturated with calcium and magnesium salts and has high concentrations of sulphate and chloride ions; it also contains relatively large quantities of hydrogen sulphide and carbon dioxide gases (FAO 2007). The brackish water from some of these deep aquifers is usually used without treatment for agricultural purposes, and for limited domestic purposes in some locations in Saudi Arabia, Bahrain, Qatar, and the United Arab Emirates. The groundwater of most of the deep aquifers requires treatment such as cooling, aeration to remove hydrogen sulphide and carbon dioxide gases, and lime soda processing.

These water scarcity issues in the region are intensified by climate variations and changes that alter the hydrologic cycle and many of the countries are dependent mainly on groundwater, desalination and treated wastewater (Amin et al. 2013; Chowdhury and Champagne 2006). Many groundwater aquifers within the Arabian Gulf countries are being mined in an uncontrolled and unplanned manner, either because it has not been possible to regulate the access to these aquifers and/or they are non-renewable (Osman-Elasha 2010). Unplanned groundwater mining erodes the economic and social sustainability of the communities that depend on the depleting storage. Bahrain, Kuwait, Saudi Arabia, and the UAE have resorted to desalination of seawater. Bahrain has virtually no freshwater (Riviere 1989), while three-quarters of Saudi Arabia's freshwater come from fossil groundwater (Postel 1997). Kuwait, for example, has no internal renewable water resources (FAO 2008). Natural water scarcity is further worsened by rapidly growing demands, unsustainable use patterns, increased water pollution and weak management institutions and regulations. In the region, with the exception of land serviced by spate irrigation, all irrigated production is reliant upon groundwater pumping and associated 'quanats'. The rate of water consumption in most countries in the region already exceeds the harnessed renewable water supply: at the present population growth rate, the average annual available water per indigenous capita will drop further to $\sim 100 \mathrm{~m}^{3}$ or less by the year 2020 (Håkan and Jägerskog 2006). Countries like Kuwait, Bahrain and the UAE are facing extreme situations of water scarcity (UNESCO-WWDR 2003). Out of the countries ranked in the world water development report
(UNESCO-WWDR 2003) with regard to the annual per capita total renewable water resources availability, all the countries in the Arabian Gulf region are ranked in the lowest $10 \%$. Since almost all renewable water resources in the region are in use, many countries have resorted to nonrenewable resources for agricultural, industrial and domestic purposes (FAO 2003). Some countries are overexploiting their water resources by between 10 and $20 \%$ (FAO and AQUASTAT 2012). As a result, water levels are dropping, groundwater resources are being mined, salinisation and salt water intrusion are taking place. ${ }^{1}$ For example, in Bahrain, Kuwait, Qatar, Yemen and the UAE, fossil groundwater withdrawals for irrigated agriculture far exceed the total recharge capacity. Of all the Arabian Peninsula countries, the water scarcity is more severe in Yemen which is exhausting its groundwater aquifers faster than any other country in the world (Ward et al. 2000). Water extraction from the aquifers is already $400 \%$ more than the renewable share of the aquifer (Ward et al. 2000). Water consumption is increasing every year and in the two largest urban areas, namely Taiz and the capital Sana, water resources are extremely limited (Glass 2010). Yemen already has one of the lowest annual per capita water shares in the world, estimated at 125 cubic metres, compared to the world average of 7500 cubic metres. The annual water share is projected to drop to 55 cubic metres per capita by 2030 unless drastic measures are taken. The water table is dropping by up to six metres a year and by 2025 , Sanaa could be the first capital in the world to run out of water. The country's present population of about 26 million is likely to be doubled after 20-25 years which will reduce the per capita availability of water, which is already the lowest in the world, to $55 \mathrm{~m}^{3}$ per capita per year in 2031 as against the world average of $7500 \mathrm{~m}^{3}$ per capita per year and $667 \mathrm{~m}^{3}$ per capita per year in the region (Al-Eshlah et al. 2013). As per the international norms, a minimum of $100 \mathrm{~m}^{3}$ per capita per year is necessary to meet domestic requirements alone and $1000 \mathrm{~m}^{3}$ per capita per year for food self-sufficiency. Nearly, two-thirds of Yemenis derive their livelihood from agriculture and such serious water scarcity pose dire consequences to their social and economic situation. If the water use continues at the same rate as today, the capital may run out of water within a decade (Ward et al. 2000). The rapidly declining water resource, therefore, portends serious economic implications for Yemen.

Generally, there has been a decrease in average annual internal renewable water resources (IRWR) per inhabitant (FAO and AQUASTAT 2012) in the region. The distribution of total actual renewable water resources (TARWR)

\footnotetext{
${ }^{1}$ See: http://www.fao.org/landandwater/aglw/aquastat/main/index. stm.
} 
is different because of trans-boundary river basins, with values ranging from $7 \mathrm{~m}^{3}$ per inhabitant in Kuwait and $33 \mathrm{~m}^{3}$ in the UAE. With respect to IRWR, most countries within the region have lower than the cutoff point of $500 \mathrm{~m}^{3} /$ inhabitant per year-considered to be the threshold for absolute water scarcity. With respect to TARWR, all the countries remain below this threshold: Saudi Arabia, the UAE and Yemen do not benefit from any outside contribution (dependency ratio of zero); Qatar benefits only slightly (ratio lower than $10 \%$ ); and Bahrain, Jordan and Kuwait have a high dependency ratio despite low external renewable resources.

\section{Rapid population growth and water consumption}

High population growth in combination with increase in per capita water consumption has contributed to increase in water consumption. Population growth triggers not only direct domestic water consumption but also the consumption of agricultural, industrial and other products, and energy use. In many countries, public water demand rises as a result of population growth and increased standards of living (UN Water 2012). The Arab Peninsula's population growth is considered one of the highest in the world. In the last four decades, the Arabian Gulf countries have experienced rapid economic growth due to the sudden increase in these countries oil revenues, which have led to a fast increase in their economic base and rapid improvement in the standard of living (Mirkin 2010). From 1998 to 2008, real GDP grew at an average rate of $5.2 \%$ annually for the GCC, with the population increasing at an average rate of $14 \%$ annually for the same time period (EIU 2010). The population in the countries of the region increased almost twofold during the period 1970-1990, from 17.8 to 33.5 million (UN Water 2012). In addition to the marked improvement in the standard of living and health, the large increase in the population is also due to the influx of a large number of expatriates to meet the fast-growing development demand for manpower; recent figures on expatriate population in the GCC countries range from $25 \%$ in Oman to $90 \%$ in the UAE (World Bank 2005). Net migration accounts for over a quarter of total population growth in the Arabian Gulf countries. In Kuwait, Qatar and the United Arab Emirates, population growth is higher from net migration than from natural increase (Mirkin 2010). By 2020, the total population of the Arab Gulf states, including Yemen, is forecast to increase by more than a third, to 70 million people (EIU 2010) (Fig. 2) and to approximately 120 million by 2050 (see Table 4) (UNESCO 2009). The vast majority will be under 25 years of age.

Reflecting the rapid population growth witnessed by these countries since the discovery and exploitation of vast

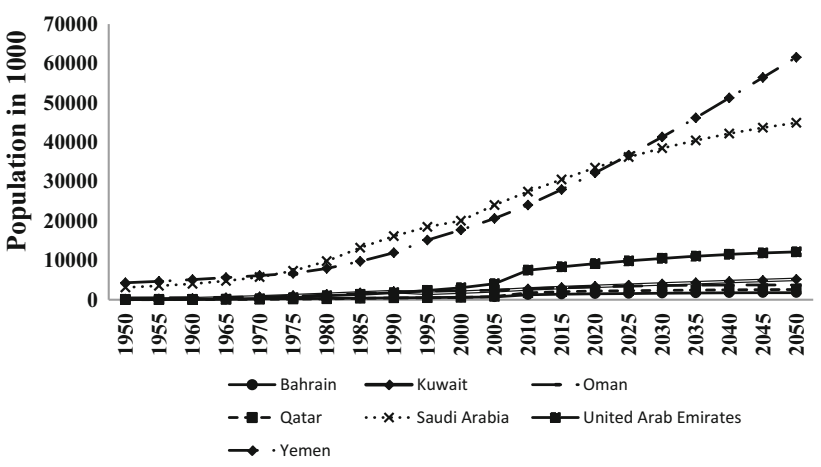

Fig. 2 Showing population for the Arabian Peninsula countries up to 2050. 1915-1950 data are based on projections Data source: United Nations, Department of Economic and Social Affairs, Population Division (2012). World Urbanization Prospects: The 2011 Revision, CD-ROM Edition

oil reserves, the overall per capita freshwater availability fell from about $680 \mathrm{~m}^{3}$ in 1970 to about $180 \mathrm{~m}^{3}$ in 2000 . Sustaining the high economic growth rates means meeting the ever-increasing demand for energy and freshwater (Bachellerie, 2012). If current population growth rates, water management approaches, water use practices and patterns continue, annual water demand may reach more than 50 BCM by the year 2030 (Al-Zubari 1997). With the anticipated future limited desalination capacity and wastewater re-use (Chowdhury and Champagne 2006), this demand will have to be met mainly by further mining of groundwater reserves, with its negative impacts of fast depletion and loss of aquifer reserves and the deterioration of water quality and salinisation of agricultural lands, of which these resources usefulness is questionable with the expected deterioration of their quality. Under these circumstances, water will become an increasingly scarce commodity, and would become a limiting factor for further social, agricultural and industrial development, unless major review and shifts in the current policies of population and adopted less-reliance on imported food are made, and an appropriate and drastic measures in water conservation are implemented (Table 2).

\section{Water consumption by sector}

The dry climate in the region creates major irrigation needs. Data on water withdrawal by sector refer to the gross quantity of water withdrawn annually for a given use. Table 3 presents the distribution of water withdrawal by country for the three large water-consuming sectors: agriculture (irrigation and livestock watering), water supply (domestic/municipal use) and industry. Total annual water withdrawal for Arabian Peninsula countries is $271.5 \mathrm{~km}^{3}$, which is around $7 \%$ of world withdrawals (FAO 2003; UN 
Table 2 Freshwater withdrawal for each of the Arabian Peninsula countries by Sector Data Source: FAO and AQUASTAT 2012

\begin{tabular}{|c|c|c|c|c|c|c|}
\hline Country & $\begin{array}{l}\text { Domestic } \\
\text { use }(\%)\end{array}$ & $\begin{array}{l}\text { Industrial } \\
\text { use }(\%)\end{array}$ & $\begin{array}{l}\text { Agricultural } \\
\text { use }(\%)\end{array}$ & $\begin{array}{l}\text { Domestic } \\
\text { use }\left(\mathrm{m}^{3} / \mathrm{p} / \text { year }\right)\end{array}$ & $\begin{array}{l}\text { Industrial } \\
\text { use }\left(\mathrm{m}^{3} / \mathrm{p} / \text { year }\right)\end{array}$ & $\begin{array}{l}\text { Agricultural } \\
\text { use }\left(\mathrm{m}^{3} / \mathrm{p} / \text { year }\right)\end{array}$ \\
\hline Bahrain & 50 & 6 & 45 & 221 & 27 & 199 \\
\hline Kuwait & 44 & 2 & 54 & 132 & 6 & 162 \\
\hline Oman & 10 & 1 & 88 & 45 & 5 & 400 \\
\hline Qatar & 39 & 2 & 59 & 115 & 6 & 174 \\
\hline Saudi Arabia & 9 & 3 & 88 & 81 & 27 & 793 \\
\hline UAE & 15 & 2 & 83 & 127 & 17 & 705 \\
\hline Yemen & 8 & 2 & 90 & 11 & 3 & 126 \\
\hline
\end{tabular}

Table 3 Past and projected water demand (million cubic metres) in the Arabian Peninsula for the years 2000 and 2025 Data Source: World Bank 2005

\begin{tabular}{|c|c|c|c|c|c|c|c|c|c|}
\hline \multirow[t]{2}{*}{ Country } & \multicolumn{3}{|l|}{2000} & \multicolumn{3}{|l|}{2025} & \multicolumn{3}{|c|}{ Total demand } \\
\hline & Domestic & Agriculture & Industrial & Domestic & Agriculture & Industrial & 1990 & 2000 & 2025 \\
\hline Bahrain & 169 & 124 & 26 & 230 & 271 & 73 & 223 & 319 & 574 \\
\hline Kuwait & 375 & 110 & 105 & 670 & 140 & 160 & 383 & 590 & 970 \\
\hline Qatar & 90 & 185 & 15 & 230 & 205 & 50 & 194 & 290 & 485 \\
\hline Oman & 170 & 1270 & 85 & 630 & 1500 & 350 & 1236 & 1525 & 2480 \\
\hline UAE & 750 & 1400 & 30 & 1100 & 2050 & 50 & 1490 & 2180 & 3200 \\
\hline Saudi Arabia & 2350 & 15,000 & 415 & 6450 & 16,300 & 1450 & 16,300 & 17,765 & 24,200 \\
\hline Yemen & 360 & 3100 & 60 & 840 & 3800 & 137 & 2899 & 3520 & 4777 \\
\hline Total & 4264 & 21,189 & 736 & 10,150 & 24,266 & 2270 & 22,725 & 26,189 & 36,686 \\
\hline
\end{tabular}

Water 2012). About $84 \%$ of inventoried withdrawals are by agriculture, which is higher than the value for global agricultural water withdrawal $(70 \%)$. However, this figure varies by country (Table 3). In Saudi Arabia, Oman and Yemen, agricultural withdrawal accounts for more than $85 \%$ of the total water withdrawal, while in Bahrain, Kuwait and Qatar it represents less than $60 \%$.

The agricultural sector is currently coming under various types of pressure. Firstly, it is under pressure to produce more food to help reduce food import expenditure, which is very high for the region. This requires both an expansion of agriculture that will increase productivity per hectare as well as the total area under agriculture. Saudi Arabia and the United Arab Emirates account for the highest annual per capita withdrawal with 963 and $889 \mathrm{~m}^{3}$ per inhabitant, respectively (FAO 2003; UN Water 2012). Municipal water withdrawal per inhabitant is approximately $90 \mathrm{~m}^{3}$ per year for Arabian Peninsula as a whole, with variations between countries from $13 \mathrm{~m}^{3}$ per inhabitant in Yemen to $245 \mathrm{~m}^{3}$ per inhabitant in Bahrain. Industrial water withdrawal per inhabitant is $70 \mathrm{~m}^{3}$ per year for the region, on average. However, this figure also varies considerably at country level. In some countries, it amounts to less than $10 \mathrm{~m}^{3}$ per inhabitant per year, especially Yemen (UN Water, 2012), where industrial water withdrawal is $3 \mathrm{~m}^{3}$ per inhabitant per year. In most of these countries, ground water is the main source of freshwater used for irrigation.

Given the low recharge rate due to low precipitation, ground water resource is threatened by over withdrawal. This puts the region's irrigated agriculture at risk and leads to saltwater intrusion in aquifers close to the seas (Chaudhuri and Srinivasulu 2014). Low water use efficiency in irrigated agriculture, therefore, exacerbates the water scarcity problem. According to FAO (2003), water use efficiency is about $40 \%$. Figures from the World Water Development Report (UNESCO-WWDR 2003) show that countries like Kuwait, Bahrain and United Arab Emirates are facing extreme situations of water scarcity (see Table 1). Out of 182 countries ranked in the UNESCO-WWDR (2003) with regard to the annual per capita total renewable water resources availability, more than half of the countries in the region are ranked in the lowest $10 \%$. This has caused almost all renewable water resources to be in use, and many countries have resorted to the use of their non-renewable resources for agricultural, industrial and domestic purposes (FAO 2003).

The intensive use of groundwater resources from shallow and deep aquifers to meet rising demand has led to further exploitation of water resources in excess of natural 
renewability and also resulted in the pollution of the existing groundwater aquifers due to the intrusion of saline seawater (especially in the coastal areas) and the up-coning of brackish and saline water supplies from lower aquifers. This is particularly serious in Oman, Bahrain and Qatar, and recovery may take generations (UN Water 2012). The increasing population pressure combined with urbanisation and economic development will increase water demand, leading to: an even greater pressure on the cities and their infrastructure, public services, housing and jobs; and an increased claim on water that is presently used for irrigated agriculture. By necessity, desalination has become a major component of the water-supply system in these countries for providing water to satisfy domestic requirements. Competition among sectors over utilisation of available groundwater sources in some of the countries has created water deficits. Rising demand is not only placing pressure on water resources, especially the most easily accessible sources, but also brings about an entirely new progression of environmental concerns and their associated development costs.

Domestic and industrial water requirements for the countries of Saudi Arabia, Bahrain, Kuwait, Qatar, Oman, and the United Arab Emirates are satisfied through desalination and a limited amount of groundwater from both shallow and deep aquifers; Yemen relies solely on groundwater resources for all sectors. In all GCC countries and Yemen, agricultural requirements are met through abstraction of water from the shallow alluvial aquifers located in the coastal strips and inland basins, and from deep aquifers covering most of the Arabian Peninsula. In Saudi Arabia, rapid expansion of agricultural activities has resulted in substantial increases in water demand, leading to extensive mining of the deep aquifers. Likewise, agricultural water demand has sharply increased in the countries of Bahrain, Qatar, Oman, and the United Arab Emirates, where groundwater reserves are being mined. This agricultural development is a direct result of government policies encouraging self-sufficiency in food production. Government incentives and subsidies have made it possible for large areas to be cultivated, placing great strain on the existing groundwater resources.

Total water demand for agricultural, industrial, and domestic purposes for all the countries in the region increased, during the period 1980-1990, from 6.6 to 22.5 $\mathrm{BCM}$, an almost fourfold increase, resulting from high population growth, and the need for food production. The major consumers were Saudi Arabia, Yemen, the United Arab Emirates, and Oman. Water requirements are expected to reach $26.2 \mathrm{BCM}$ by the end of the twentieth century, and 36.7 BCM by the year 2025, as shown in Table 3. Agriculture accounts for the majority of water use (more than $70 \%$ ), followed by the domestic sector (FAO
2007). Industrial activities in most of the countries of the Arabian Peninsula are limited and have contributed to only small increases in total water requirements, when compared with the domestic and agricultural sectors. Industrial water demand in 1990 reached $0.30 \mathrm{BCM}$, with percentages ranging between 0.4 and $7.6 \%$. Industrial demand is projected to reach 0.7 and $2.3 \mathrm{BCM}$ in the years 2000 and 2025 , respectively, with the highest demands being in the countries of Saudi Arabia, Kuwait, and Oman.

Increase in urban water demand is also another major issues. Two factors explain the current alarming increase in urban water demand. The first is the rapid population growth and the second is the rise in per capita consumption. As mentioned in the previous section, average population growth in the region is indeed among the highest in the world (around 3.5-6.0 \% per annum) (World Bank 2005). More strikingly, the average daily water consumption per capita ranges between 300 and $750 \mathrm{~L}$, which ranks the highest in the world. This volume has dramatically increased over the last three decades (UN Water 2012). Imbalances between increasing water demand and existing limited water resources are being experienced by the countries of the Arabian Peninsula. During the last decade, water demand in all sectors increased dramatically as a result of high population growth (and is projected to continue on the upward trend; see Table 4), improvement in the standard of living, efforts to establish self-sufficiency in food, and promotion of industrial development. For instance, the annual water demand in Saudi Arabia was 20,740 million cubic meters (MCM) in 2000 and increased to $22,480 \mathrm{MCM}$ in 2005; an average annual increase of approximately $1.7 \%$ (Chowdhury and Champagne 2006). Projections for 2100 show that 111,500 MCM will be required to meet the population water needs in Saudi Arabia, the largest and most populous of the GCC countries. The deficit is being met through sea-water desalination and mining of groundwater resources. In absolute terms, three countries (Saudi Arabia, the United Arab Emirates and Kuwait) are by far the largest users of desalinated water, accounting for $77 \%$ of the region's total. Saudi Arabia uses an annual 1033 MCM and United Arab Emirates and Kuwait 950 and $420 \mathrm{mcm}$, respectively (FAO and AQUASTAT 2012).

The scarcity of renewable water resources and the growing gap between demand and available supply of domestic water supply, due to rapid growth in population and urbanisation, is therefore a major challenge. The region mainly depends on groundwater, desalination and treated wastewater (UNESCO 2009). Bahrain, Kuwait, Saudi Arabia, and the United Arab Emirates have resorted to the desalinisation of seawater from the Gulf. Bahrain has virtually no freshwater, while three-quarters of Saudi Arabia's freshwater come from fossil groundwater. Natural water 
Table 4 Total population 1970-2050 Data source: Data source: United Nations, Department of Economic and Social Affairs, Population Division (2012). World Urbanization Prospects: The 2011 Revision, CD-ROM Edition

\begin{tabular}{lccr}
\hline Country & \multicolumn{3}{c}{ Total population (thousands) } \\
\cline { 2 - 4 } & 1970 & 2010 & 2050 \\
\hline Bahrain & 220 & 807 & 1277 \\
Kuwait & 744 & 3051 & 5240 \\
Oman & 747 & 2905 & 4878 \\
Qatar & 111 & 1508 & 2316 \\
Saudi Arabia & 5745 & 26,246 & 43,658 \\
United Arab Emirates & 225 & 4707 & 8253 \\
Yemen & 6391 & 24,256 & 53,689 \\
\hline
\end{tabular}

scarcity is further worsened by rapidly growing demands, unsustainable use patterns and increased water pollution.

Besides the high amount of water consumed by the agriculture sector, residential and cities landscaping also consumes so much water, especially during summer as the evaporative demand dramatically increases with increase in the temperature which can rise to as high as $48{ }^{\circ} \mathrm{C}$ at the peak of summer. The amount of water required by residential landscaping is a function of the areal extent of residential landscaping (i.e. tree/shrub or turf grass), the water-loss rate for different landscaping types, the efficiency with which the landscape is irrigated, and local climatic factors (i.e. reference evapotranspiration and precipitation) (Lowry et al. 2011). No study has been conducted to quantify this but going by the high amounts of domestic and municipal water consumption it can be assumed that most of this goes towards watering plants and lawn. With increase in landscaped areas as population grows and conditions become drier and hotter, water consumption would obviously increase significantly unless drastic measures such as heavy tariffs and conservation measures are taken.

Domestic water demand increases can also be attributed to a lack of strict conservation measures and price signalling mechanism to consumers. Domestic water use in all GCC countries increased from around 2.8-5.1 BCM during 1990-2000. Drinking water use alone is expected to reach around 8.5 BCM in the year 2025 if the current trend continues and no policy changes are made (World Bank 2005). All GCC countries will have to allocate significant amounts of financial resources for the construction of new seawater desalination plants to meet ever-increasing water demands as well as wastewater treatment plants for handing the resulting wastewater discharge. The huge investment needs may constrain the fiscal conditions of the GCC countries even while their substantial oil revenues are sustained.

\section{Unsustainable Water Consumption}

In spite of its scarcity, water is often over consumed (and sometimes wasted) in the region as a result of its low price due to heavy subsidy by the governments. Water tariffs are generally quite low, representing on the average no more than $10 \%$ of cost, which implies that no incentives exist under current policies for consumers to save water. Furthermore, water metering and billing are only loosely applied to nationals. In some countries such as Kuwait, water is made available to nationals almost free of charge with the exception of a small nominal flat monthly fee that is charged irrespective of the amount of water used. Hence, there exists a substantial difference in water consumption resulting from pricing differentiation between metered and non-metered water use, the former estimated at around $260 \mathrm{~L}$ against $1400 \mathrm{~L}$ per capita per day for the latter (Brook et al. 2006; Håkan and Jägerskog 2006). This illustrates the fact that the lack of metering and price signalling constitutes the fundamental cause of wasteful water use. In fact subsidies have been instrumental in driving a very material increase in domestic demand. Saudi Arabia currently subsidises more than $92 \%$ of the total cost of producing water (Ouda 2013). The average cost of municipal water in the Kingdom is the lowest in the world. Qatari nationals receive the electricity and water for free, while non-Qatari expatriates pay for the services at a subsidised rate, which is approximately $70 \%$ of production and distribution cost (Al-Mohannadi 2009).

In the UAE, the average Emirati-national is subsidised by around $89 \%$ for water and electricity combined while non-nationals are subsidised by around $59 \%$ for the two services (EIU 2010). The more energy and water are subsidised, the greater the demand is for those goods as their true cost of production becomes externalised (EIU 2010). This is demonstrated by the exceptionally high energy and water uses per capita in the Arabian Gulf countries (IEA 2010). In terms of water use, the water footprints of Qatar and UAE stand well over $3000 \mathrm{~m}^{3}$ per year, more than double the world average (Saif 2012).

The current policies of heavily subsidising the water sector could become counterproductive in the future. Heavy reliance on subsidies will not only exacerbate rapidly rising water demand, but will also place considerable burden on national budgets as substantial amount of water will have to be supplied by very costly desalination plants. Even though newer and more cost efficient desalination technologies have become available, water subsidies alone could use up to $10 \%$ of oil revenues in some GCC countries by 2025 (Brook et al. 2006; UN Water 2012). While agriculture consumes around $60-90 \%$ of water, it accounts for only $2-7 \%$ of GDP in Saudi Arabia, the 
United Arab Emirates, and Oman. The agriculture sector is much more insignificant in Bahrain and Qatar with less than $1 \%$ of GDP while still using around 50-60\% of water. Irrigation water is generally used in a wasteful manner, mainly through usage of traditional flooding and furrow irrigation techniques and for cultivating low value, high water-consumptive crops, without considering its economic opportunity cost for potable and urban/industrial purposes. In this predominately desert region, losses can exceed $50 \%$ of pumped groundwater (Håkan and Jägerskog 2006). Generous subsidies for agriculture have enabled farmers to produce crops which have low returns to water, such as forage crops, alfalfa, and low value-added vegetables grown in open fields (FAO 2007). These subsidies distort costs and revenues, and many of the agricultural activities in the Arabian Gulf countries are financially profitable only because of government subsidies and incentives, notwithstanding the high opportunity cost of water. In May 2012, at the global summit for water in the oil and gas sector, the undersecretary of the Ministry of Environment and Water announced that the UAE will be investing US $\$ 13.89$ billion in new desalination plants and distribution networks from 2012 to 2016 (EIU 2010; Malek 2013). Indeed subsidies have been instrumental in driving a very material increase in domestic demand for water.

Given the low cost recovery and the rapidly increasing demand, water subsidy will become a very heavy load on the governments' budgets. In Oman, for example, the country's budget for 2008 included a US\$159 million subsidy for the water sector. ${ }^{2}$ In Saudi Arabia, the largest and most populous country in the region, the government subsidy to water production is projected to dramatically increase reaching about US\$ 6472 million by the year 2020 (Ouda 2013). With projected population growth rate driving demand for water upwards, the government budget will be overly inflated. Already public spending on water accounts for between 1 and $5 \%$ of GDP in the region, and as much as one quarter of public capital expenditure (EIU 2010). Yet much of the public spending does not always generate the expected benefits. Artificially cheap water, due to heavy subsidy, has enabled the development of water-intensive crops in a region that has no natural advantage in producing these, but where governments provide generous subsidies to ensure future food supplies. Given recent trends in the growth of water demand, the fiscal burden is likely to be very heavy, particularly in Kuwait and Saudi Arabia. From 1998 to 2008, real GDP grew at an average rate of $5.2 \%$ annually for the GCC, with the population increasing at an average rate of $14 \%$ annually for the same time period (EIU 2010). However, to

\footnotetext{
2 http://www.ooskanews.com/middle-east-africa/oman-159-millionusd-water-sector-subsidy-2008-budget.
}

achieve this level of economic development means meeting the ever-increasing demand for energy and freshwater (Beaumont 2002; Bachellerie 2012).

Unrealistically, low water cost inevitably results in overconsumption as there is little awareness of the scarcity of water or the substantial cost in producing desalinated water and, therefore, no incentive to curb overuse. Therefore, the only realistic way to control the very high consumption of water within the water-scarce region will be to increase the cost of water with the hope that high water costs will compel consumers to use less of the resource and/or employ more prudent water conservation measures. This, however, may entail heavy political costs and may need a very careful analysis before implementation. To reduce water misuse, the governments can implement a waterpricing policy with two rates components, one fixed and the other volume based. The fixed charge is payable by all consumers regardless of the level of consumption and includes a free allowance of a determined quantity per quarter to cushion the low-income earners. The volumebased charges can be divided into pre-determined ascending volumetric blocks, that is, consumption in each succeeding block is charged at a higher rate than the previous block. This way larger consumers end up paying more and would, therefore, be motivated to conserve water and avoid wasteful expenditures. The UAE has adopted this approach by slightly increasing water and electricity tariff (Todorova 2014). However, the increase still seems too low to encourage sustainable consumption.

\section{Climate change}

As already mentioned, the Arabian Peninsula region has an arid climate with less than $200 \mathrm{~mm}$ per year average rainfall, a very high evaporation rate $\left(2-3 \mathrm{~m}^{3}\right.$ per year), a low groundwater recharge rate $(<4 \%$ of total annual water used) and no reliable, perennial surface water resources, thus the severity of its arid climate and water scarcity. Giorgi (2006) identifies the Middle East and North Africa (MENA) region among the most physically sensitive regions to climate change. Within MENA, Arabian Peninsula is considered one of the most vulnerable regions to climate change impacts, on account of its water scarcity, which is one of the highest in the world (UN Water 2012). The IPCC report estimates an increase in temperature in the region of up to $2{ }^{\circ} \mathrm{C}$ in the next $15-20$ years, and over $4{ }^{\circ} \mathrm{C}$ for the end of the century (IPCC 2007). These climate projections paint a grim picture with conditions getting hotter, drier and less predictable climate, and a $20 \%$ decline in precipitation (IPCC 2007) resulting in a drop in water runoff by $20-30 \%$ in most of the region by 2050 , mainly due to rising temperature and lower precipitation 
(Milly et al. 2005). Reduced stream flow and groundwater recharge might lead to a reduction in water supply of $10 \%$ or greater by 2050 . In Saudi Arabia, for example, a $15-20 \mathrm{~mm}$ decrease in precipitation in the western coast and northern regions near Tabuk is expected during summer. Northern and eastern regions will experience drought (http://unfecc.int/resource/docs/natc/saunc1.pdf). This will result in water shortages and as well increase soil and ground water salinity. The case is no better in the United Arab Emirate where annual average temperatures in 2050 are projected to be between about 1.6 and $2.9^{\circ} \mathrm{C}$ warmer than they were over the period 1961-1990, and between 2.3 and $5.9^{\circ} \mathrm{C}$ warmer by 2100 . Rainfall in the UAE is projected to be between $20 \%$ less in 2050 than levels over the period 1961-1990, and between $45 \%$ less by 2100 . The situation is the same for the other Arabian Gulf countries. The consequence of these climate scenarios is severe shortage of water resources and increasing soil and water salinity in some coastal aquifers through direct salt water intrusion. To the south east of the region (in Yemen), increased water scarcity and reduced water quality, increased drought frequency and expansion of desertification are predicted.

Although desalination plant facilities are being expanded, the governments are looking to further develop lower cost solutions such as flash flood dams to refill underground aquifers and increase water conservation to promote better use of natural water supplies. In the UAE, for example, more than 113 recharge and storage dams have been constructed to utilise the estimated $150 \mathrm{Mm}^{3}$ per year in the wadis located in the 15 main catchment areas (Ministry of Energy (MoE) United Arab Emirates 2006). The UAE's nine largest recharge dams have a combined capacity to collect $47 \mathrm{Mm}^{3}$ of flash flood water a year while the other 104 smaller dams have a combined capacity to collect about $60 \mathrm{Mm}^{3}$ of flood water each year (Ministry of Energy (MoE) United Arab Emirates 2006). In Saudi Arabia, the government has constructed dams throughout the country so as to utilise the surface runoff water to tap seasonal flood water flowing through the wadis. They are basically used to trap the surface water after frequent flash floods. Their numbers are increasing year by year totalling 232 in the year 2012 compared to 223 in the year 2004 (Saud et al. 2013). However, with drier conditions in future due to less rainfall, the amount of water collected from these dams will reduce resulting in even lower recharge of groundwater. This would mean that the governments increase production from desalination plants to meet the rising water demands, further increasing government operational costs, especially given the already bloated budget to support utilities subsidies.

\section{Socio-economic impacts}

As outlined in the previous section, the main water resources management challenges in the Arabian Gulf region are the unsustainable use of groundwater resources with its ramification on these countries socio-economic development, and the escalating urban water demands and its heavy burden on their national budget and negative impacts on the environment. Given the scenario, it would be a great challenge to sustain adequate water supply in the future without expensive socio-economic and environmental impacts.

If current population growth rates, water management approach, water use practices and patterns continue, annual water demand may reach more than $50 \mathrm{BCM}$ by the year 2030 (Al-Zubari 1997). With the anticipated future limited desalination capacity and wastewater reuse, this demand may have to be met mainly by further mining of groundwater reserves which would result in negative impacts of rapid depletion and loss of aquifer reserves and the deterioration of water quality (through salinisation of ground water located close to the seas) and salinisation of agricultural lands, of which this resource usefulness is questionable with the expected deterioration of their quality. Under these circumstances, water will become an increasingly scarce commodity, and would become a major limiting factor for further social, agricultural and industrial development in the region, unless major review and changes in the current policies of population and adopted food self-sufficiency are made, and an appropriate and drastic measures in water conservation are implemented.

Many of the oil-rich Arabian Peninsula countries focus on diversifying their economies to move away from oilbased economy to service sector. The tourism sector is among those poised to be the focus of these governments and is among the sectors expected to form the engines of economic growth and diversification in countries such as the UAE (Abu Dhabi Vision 2030), Qatar, Kuwait and Oman (Gössling et al. 2012). Tourism is also a future growth sector, expected to add significantly to the number of passengers using the regional airports.

http://www.thetravelfoundation.org.uk/images/media/ Tourism_water_resources_in_destinations_report_Aug 2011.pdf.

However, the ever-increasing demand for water coupled with the effects of climate change is escalating pressure on water resources in the region, including in many coastal and island tourist destinations. Various tourist activities add to water use, with prominent example being golf. The consumption of water by golf courses varies considerably, depending on soils, climate and golf course size (Throssell et al. 2009). In dry climates, such as prevails within the 
Arabian Peninsula, water used in irrigating golf courses is obviously much higher given the extremely high evaporative water loss. For instance, Van der Meulen and Salman (1996), report that an 18-hole golf course in a Mediterranean sand dune system is sprinkled with $0.5-1$ million $\mathrm{m}^{3}$ of fresh water per year. Throssell et al. (2009) reported annual water of up to $566,000 \mathrm{~m}^{3}$ in the desert states of the Southwest (USA). Freshwater is also needed to maintain the gardens and landscaping of hotels and attractions, and is embodied in tourism infrastructure development, food and fuel production (Hof and Schmitt 2011). These waterintensive activities associated with the hotel industry will, therefore, pose an even bigger threat to scarce water resources.

These factors will inevitably have future impacts on the tourism sectors in these destination countries. Water scarcity could as well become a limiting factor for tourism development, with serious economic consequences in formerly popular destinations such as the UAE, Oman and Qatar.

At a time when the already critical water-supply situation in the region is expected to be exacerbated by climate change and rapid population increase, tourist resorts are extending their tourist base to activities that increase permanent water demand for facilities and leisure structures (golf courses, spas, aquatic parks, swimming pools and irrigated gardens). Garden irrigation may account for more than $70 \%$ of water consumption in summer when temperatures soar. By 2020, tourism's contribution to water use is likely to increase with increased tourist numbers, higher hotel standards and the increased water intensity of tourism activities (UNWTO/UNEP/WMO 2008).

\section{Future scenario}

Water demand for each individual country, based on current trends and projections, is shown in Table 3. Water shortages are expected to increase as a result of increased demand and limited renewable supplies. Water resources from renewable groundwater, desalination, and reclaimed waste water are already insufficient to meet expected demand. It is expected that, in order to offset the imbalance between supply and demand, mining of groundwater, especially from the deep aquifers, may be required to meet agricultural and other demands. Expected domestic and industrial demand increases in the next 30 years may also necessitate the construction of additional desalination and treatment plants to produce water and treat waste water, for most of the countries in the region unless strict integrated management approaches, including water-conservation measures and effective management schemes, are implemented and good-quality groundwater is used solely for domestic and industrial use. Falling groundwater tables and reduced river flows will not only impact the social and economic dynamics of the region but will also "close" river systems and reduce ecosystems goods and services. Increasing population pressure resulting from urbanisation and economic development will increase water demand, leading to an even greater pressure on the cities and their infrastructure, public services, housing and jobs, and an increased claim on water that is presently used for irrigated agriculture.

Water use has been growing at more than twice the rate of population increase in the last century, and, although globally there is no water scarcity as such, an increasing number of regions are chronically short of water. The situation will be exacerbated as rapidly growing urban areas place heavy pressure on neighbouring water resources. Obviously, the drier (arid and semiarid) regions affected by droughts and wide climate variability, and increasing economic development resulting in the population growth have acute water scarcity. Irrigated agriculture, which represents the bulk of the demand for water in these countries, is also usually the first sector affected by water shortage, resulting in a decreased capacity to maintain percapita food production while meeting water needs for domestic, industrial, and environmental purposes.

If present domestic consumption patterns continue unaltered, most countries of the peninsula will be required to mine their groundwater resources further and to allocate financial resources towards the construction of new desalination plants and support facilities with capacities capable of handling increasing demands. Also, a large number of waste-treatment plants will be required to handle the resulting wastes. This huge investment may result in considerable economic strain, especially in those countries with limited financial resources.

Overcoming future water-supply limitation problems and increasing water demand in all countries of the Arabian Peninsula requires the implementation and enhancement of water management practices and investment in efficient low cost water desalination and waste water treatment technologies to provide additional sources (Khouri 2003). Efficient management of water resources in each of the countries of the Arabian Peninsula may include supplyand-demand control, strengthening of both institutional arrangements and capacity building, and integrated planning, to formulate and implement water policies and strategies.

The increasing imbalance between water supply and demand has compelled many countries of the Arabian Peninsula to augment supplies through sea-water and brackish water desalination, reuse of renovated waste water, groundwater recharge schemes, and the implementation of conservative water-conservation measures. To 
alleviate future water shortages, current supply augmentation schemes and demand-management measures need to be enhanced with respect to coverage and enforcement. In addition, further efforts need to be made towards the development and management of water resources, based on an integrated approach. Viable options for the development and management of water resources may involve some or all of the measures discussed below.

With future desalination capacity and wastewater reuse anticipated to be limited, the increasing water demand will have to be met mainly by further mining of groundwater reserves, with the associated negative impacts of depletion and loss of aquifer reserves, deterioration of water quality, and salinisation of agricultural lands (Håkan and Jägerskog 2006). Under these circumstances, water will become an increasingly scarce commodity and will become a limiting factor to further social, agricultural, and industrial development. Water scarcity is also expected to contribute to increased health risks. To ensure a sustainable future, water management strategies must include balanced socio-economic choices on the use of aquifer storage reserves, demand management to encourage transition to a less water-dependent economy, and plans for the eventual replacement of the water source with another as it is depleted. Desalination plants are problematic. They are expensive, have limited operation lives of only 15-25 years, depend on fossil fuel, and pollute the surrounding air and water.

Virtual water is another viable option. The total amount of water that is used to produce a product is referred to as virtual water. Using this concept, international food trade has been analysed in terms of virtual water flows (AlZubari 1997). Simply put, the virtual water flow between two nations is equal to the volume of virtual water that results from product trade. For example, most of the major food exporters have highly productive rain-fed agriculture, while most food importers rely on irrigation or low output rain-fed systems (see Hoekstra and Hung 2002). Trade in virtual water can reduce consumptive water use in agriculture, as well as industry, provided that exporters achieve higher water productivity than importers. It can make good sense for countries that are net-importers of virtual water to seriously consider their strategies and policies towards domestic irrigated food production. Trade in virtual water generates water savings for importing countries-it is estimated that Egypt's maize imports in the year 2000 generated a saving of about $2700 \mathrm{MCM}$ of water (FAO 2003). Continued water scarcities will affect the region's social and economic potential, increase land vulnerability to salinisation and desertification and raise the risk for political conflict around the limited water available.

It is worth mentioning that there have been some initiatives by countries such as the United Arab Emirates and
Saudi Arabia to address the aforesaid water problems. Some are very effective and play an important role in easing the problems. The following are some of the measures being taken by these countries:

- Revising and modernising water legislation and strengthening the mechanisms for its implementation.

- Reforming of institutions, and legal reform programmes to overcome the fragmentation of responsibilities in the water and agriculture sectors.

- The use of economic incentives to encourage various consumers (household, commercial, industrial) to conserve water and power resources.

- Programmes for public water and energy awareness that will encourage water and energy conservation.

- Encouraging private sector role in constructing, operating and maintaining various water and energy projects.

- Recycling of treated sewage wastewater for various applications.

- Reviewing the subsidy policy with a view of incorporating realistic water pricing to minimise water misuse. The UAE government has recently (beginning January 2015) revised water and electricity tariff upwards, especially for the expatriates and reduced subsidy for the locals with the aim of sending a message across to conserve the scarce natural resources (Halligan 2014) and reduce the 'big burden that subsidies are posing in the government's finances' (Todorova 2014). Although the increase is minimal, it is considered by experts a positive initial step that may translate into major savings to the government in subsidies.

- Introduction of effective and efficient national campaigns to rationalise water use by consumers in addition to the other measures can be useful as well (Al-Zahrani and Baig 2011).

To cope with future water demands, there is a need to seriously devote efforts to management approaches that will provide optimal allocation and efficient utilisation of the scarce water resources. Concurrently, serious efforts need to be made towards reducing water requirements through demand-management measures. It is essential that the countries within the Arabian Gulf establish water management plans that incorporate and emphasise integrated water-resource development and management. Water policies and strategies should address the allocation of water in accordance with market values and water conservation. Key policies should, therefore, address long-term programmes for agricultural development and review of water-pricing subsidies, development and application of appropriate technology and institutional arrangements. 


\section{Conclusions}

Water is becoming a strategic, limited resource within the Arabian Peninsula that needs a careful attention. Water-related problems and concerns are not new, but now they are becoming more and more obvious and internationalised due to global interdependence. Rapid population growth and unsustainable water consumption has exacerbated water scarcity in the Arabian Peninsula. While natural factors such as intermittent droughts and limited freshwater reserves can cause scarcity, high population growth imposes additional pressures. In the last decades, rapid population growth, unsustainable water consumption coupled with agricultural expansion, has significantly increased demand on groundwater resources. The agricultural sector is by far most demanding in terms of water withdrawal compared to any other sector. In many countries in the region, agricultural water consumption is quite high accounting for more than $70 \%$ of total water consumption.

Large increases in water demand with little recharge have strained groundwater resources resulting in decline in water levels and deterioration of groundwater quality. Sharp drop in groundwater tables noticed in most regions in recent years is conclusively attributed to pumping out of well water which confirmedly exceeds the level of the natural recharge. As a result, average water level, for instance, has dropped. Water demands will continue to increase, due to rising populations as well as increasing economic growth. The oilrich countries in the Arabian Peninsula have large desalination schemes to help alleviate the water stress. In Saudi Arabia, about $70 \%$ of the drinking water is provided through desalination plants. Apparently, benign desalination life cycle creates major environmental problems which are still largely ignored. All countries in the Arabian Peninsula are using more than $100 \%$ of their renewable water resources; in Kuwait, the rate is above $2000 \%$. With anticipated increased demand and effects of climate change, there is bound to be water crisis in the region if current rates of consumption continue unabated. New water governance policies including, e.g. better water tariff systems and raising awareness are, therefore, needed.

However, the Arabian Peninsula countries are at a critical juncture with regard to managing water and financial resources in a sustainable manner and securing the balanced development of economic, social and environmental conditions for their citizens and future generations. It is time to squarely face the critical problems plaguing the water sector and come up with suitable solutions to balance the major challenges ahead, mainly on how to sustain vulnerable aquifer resources, meet rapidly increasing water demands in all sectors, and make the best use of oil revenues.
Open Access This article is distributed under the terms of the Creative Commons Attribution 4.0 International License (http:// creativecommons.org/licenses/by/4.0/), which permits unrestricted use, distribution, and reproduction in any medium, provided you give appropriate credit to the original author(s) and the source, provide a link to the Creative Commons license, and indicate if changes were made.

\section{References}

Al-Alawi J, Abdulrazzak M (1994) Water in the Arabian Peninsula: problems and perspectives. In: Rogers P, Lydon P (eds) Water in the Arab World, perspectives and prognoses. Harvard University Press, Division of Applied Sciences, Cambridge

Al-Eshlah, A, Al-Rubaidi, H, and Al-Sabri, A (2013). Agriculture's contribution to solving the water crisis. National Conference for the Management and Development of Water Resources in Yemen, March 03, 2013. http://www.yemenwater.org/wpcontent/uploads/2013/03/Paper-2-B.pdf

Al-Mohannadi HI (2009) "Water Resources in the State of Qatar: Shortages and Alternatives." Background paper for GSDP and UNDP, Qatar's Second Human Development Report: Advancing Sustainable Development, Doha

Al-Zahrani KH, Baig MB (2011) Water in the Kingdom of Saudi Arabia: sustainable management options. J Animal Plant Sci 21(3):601-604

Al-Zubari WK (1997) Toward the establishment of a total water cycle management and re-use program in the GCC countries. In: Mahdi KA (ed) Water in the Arabian Peninsula, problems and policies. Ithaca Press, Reading, UK, pp 255-273

Amin MT, Alazba AA, El-Nesr MN (2013) Adaptation of climate variability/extreme in arid environment of the Arabian peninsula by rainwater harvesting and management. Int $\mathrm{J}$ Environ Sci Technol 10(1):27-36

Bachellerie IJ (2012) Renewable energy in the GCC Countries: resources, potential, and prospects. Gulf Research Center. http:// library.fes.de/pdf-files/bueros/amman/09008.pdf. Accessed 16th June 2014

Beaumont P (2002) Water policies for the Middle East in the 21st century: the new economic realities. Water Resour Develop 18(2):315-334

Brook MC, Al Houqani H, Al Mugrin A (2006) The current status and future requirements of water resources management in the Arabian Peninsula. In: Amer KM, Boer B, Brook MC, Adeel Z, Clusener-Godt M, Saleh W (eds) Policy Perspectives for Ecosystem and Water Management in the Arabian Peninsula. United Nations University International Network on Water, Environment, Hamilton

Chaudhuri S, Srinivasulu A (2014) Long-term (1930-2010) trends in groundwater levels in Texas: influences of soils, land cover and water use. Sci Total Environ 490:379-390

Chowdhury S, Champagne P (2006) Use of treated wastewater: evaluation of wastewater minimization strategies using fuzzy technique. In: Proceedings of the Conference on Advanced Technology in the Environmental Field (ATEF), Spain

Economist Intelligence Unit (EIU) (2010) The GCC in 2020: resources for the future. a report from the economist intelligence unit sponsored by the qatar financial centre authority. http:// graphics.eiu.com/upload/eb/GCC_in_2020_Resources_WEB.pdf. Accessed 22nd Jan 2014

Edgell HJ (1987) Geological framework of Saudi Arabia-groundwater resources. KAU J Earth Sri 3:267-285 
FAO (2003) Review of world water resources by country. Water Reports No. 23. ISSN 1020-1203. Rome. ftp://ftp.fao.org/agl/ aglw/docs/wr23e.pdf. Accessed 23rd July 2013

FAO (2007) FAO's Information System on Water and Agriculture (AQUASTAT). http://www.fao.org/AG/AGL/aglw/aquastat/ main/index.stm. Accessed 14th Aug 2013

FAO (2008) Irrigation in the Middle East region in figuresAQUASTAT survey-2008. ftp://ftp.fao.org/docrep/fao/012/ i0936e/i0936e00.pdf Accessed 23rd July 2013

FAO, AQUASTAT (2012) Food and Agriculture Organization of the United Nations, accessed 30 July 2012. http://www.fao.org/nr/ water/aquastat/main/index.stm. Accessed 7th Jun 2013

Giorgi F (2006) Climate change hotspots. Geophysical Research Letters 33, L08707, Implementation of Decision 1/CP.10 of the UNFCCC Convention

Glass N (2010) The water crisis in Yemen: causes, consequences and solutions. Glob Major E J 1(1):17-30

Gleick P (2012) The World's Water: the biennial report on freshwater resources, vol. 7. Island Press, Washington. doi:10.1007/978-159726-228-6. Available online at: http://link.springer.com. library.smu.ca:2048/book/10.1007/978-1-59726-228-6/page/ 1 \#section $=1000042 \&$ page $=3 \&$ locus $=64$. Accessed 23rd Mar 2015

Gössling S, Peeters PC, Hall M, Jean-Paul C, Dubois G, Lehmann LV, Daniel SD (2012) Tourism and water use: supply, demand, and security. Int Rev Tour Manage 33:1-15

Håkan T, Jägerskog A (2006) Water scarcity challenges in the Middle East and North Africa (MENA). Human Development Report 2006-Water for Human Development. Stockholm International Water Institute, Stockholm

Halligan N (2014) Abu Dhabi residents to face water, electricity charge increase from Jan 1. Arabian Business. http://www. arabianbusiness.com/abu-dhabi-residents-face-water-electricitycharge-increase-from-jan-1-571707.html Accessed 2nd Jan 2015

Hoekstra AY, Hung PQ (2002) Virtual water trade: a quantification of virtual water flows between nations in relation to international crop trade. Value of Water Research Report Series No.11, UNESCO-IHE

Hof A, Schmitt T (2011) Urban and tourist land use patterns and water consumption: evidence from Mallorca, Balearic Islands. Land Use Policy 28:792-804

IPCC (2007) Climate change 2007: impacts, adaptation and vulnerability. In: Parry ML, Canziani OF, Palutikof JP, van der Linden PJ, Hanson CE (eds) Contribution of working group II to the fourth assessment report of the intergovernmental panel on climate change. Cambridge University Press, Cambridge

Khouri J (2003) Sustainable development and management of water resources in the Arab region. In: Alsharhan AS, Wood WW (eds) Water resources perspectives: evaluation, management and policy. Elsevier Science, Amsterdam, pp 199-220

Lowry JH, Ramseyb RD, Kjelgrenc RK (2011) Predicting urban forest growth and its impact on residential landscape water demand in a semiarid urban environment. Urban For Urban Green 10:193-204

Malek C (2013) Water scarcity will be at 'alarming levels' by 2025 , GCC warned. The National, September 16, 2013. http://www. thenational.ae/uae/environment/20130916/water-scarcity-willbe-at-alarming-levels-by-2025-gcc-warned\#ixzz31uoYYZWs. Accessed 15th Mar 2014

Milly PCD, Dunne KA, Vecchia AV (2005) Global pattern of trends in stream flow and water availability in a changing climate. Nature 438(17):347-350
Ministry of Energy (MoE) United Arab Emirates (2006) Initial National Communication to the United Nations Framework Convention on Climate Change. http://unfccc.int/resource/docs/ natc/arenc1.pdf. Accessed 21st May 2014

Mirkin B (2010) Population levels, trends and policies in the Arab region: challenges and opportunities. United Nations Development Programme Regional Bureau for Arab States, Arab Human Development Report. UNDP Research Paper Series, New York, USA

Osman-Elasha B (2010) Mapping of climate change threats and human development impacts in the Arab region. Research Papers Series 03/2010; UNDP, Arab Human Development Report. http://www.arab-hdr.org/publications/other/ahdrps/paper02-en. pdf. Accessed 2nd Mar 2015

Ouda OKM (2013) Review of Saudi Arabia municipal water tariff. World Environ 3(2):66-70. doi:10.5923/j.env.20130302.05

Postel S (1997) Last oasis: facing water scarcity. Norton, New York Riviere JWM (1989) Threats to the world's water. Sci Am 261:80-94

Rogers P (2000) Water resources in the twentieth and one half century: 1950-2050. Water Resour Update 116:62-66

Saif O (2012) The future outlook of desalination in the Gulf: challenges and opportunities faced by qatar and the UAE. Desalination Process in Gulf. Green Tech Magazine. http:// inweh.unu.edu/wp-content/uploads/2013/11/The-Future-Outlookof-Desalination-in-the-Gulf.pdf. Accessed 15th September 2013

Saud AG, Mohamed F, Soliman MF, Asif U Z (2013) Saudi Arabia confronts with water scarcity: an insight. Int J Water Resour Arid Environ 2(4): 218-225. http://www.psipw.org/attachments/ article/342/IJWRAE_2(4)218-225.pdf. Accessed 2nd June 2014

Throssell CS, Lyman GT, Johnson ME, Stacey GA, Brown CD (2009) Golf course environmental profile measures water use, source, cost, quality, and management and conservation strategies. Appl Turfgrass Sci. doi:10.1094/ATS-2009-0129-01-RS (Online)

Todorova V (2014) Electricity and water price increase in Abu Dhabi should increase efficiency, experts say. The National. November 13, 2014. http://www.thenational.ae/uae/environment/electricityand-water-price-increase-in-abu-dhabi-should-increase-efficiencyexperts-say. Accessed 3rd February 2015

UNESCO-WWDR (2003). Water for People. Water for Life. The United Nations World Water Development Report (WWDR). http://unesdoc.unesco.org/images/0012/001297/129726e.pdf. Accessed on 24th June 2013

United Nations Educational, Scientific and Cultural Organization (UNESCO) (2009) Valuing water. UNESCO World Water Assessment Programme. Retrieved April 3, 2009, from http:// www.unesco.org/water/wwap/facts_figures/valuing_water.shtml. Accessed 16th May 2014

UNWTO/UNEP/WMO (2008) Climate change adaptation and mitigation in the tourism sector: frameworks, tools and practices. Accessed 23rd Jul 2015. http://sdt.unwto.org/sites/all/files/ docpdf/ccoxford.pdf. Accessed 14th July 2013

Van der Meulen F, Salman AHPM (1996) Management of coastal dunes. Ocean Coast Manag 30(2-3):177-195

Ward C, Ueda S, McPhail A (2000) Water Resources Management in Yemen. Contribution to the CDR Yemen. World Bank

Water UN (2012) Global Annual Assessment of Sanitation and drinking-water (GlAAS) 2012 report: the challenge of extending and sustaining services. UN, New York

World Bank (2005) A Water Sector Assessment Report on the Countries of the Cooperation Council of the Arab States of the Gulf. World Bank Report No. 32539-MNA, Washington, DC 